\title{
Flow Injection Spectrofluorimetric Determination of Cystine and Cysteine
}

\author{
Ali A. Ensafi, * B. Rezaei and S. Nouroozi \\ Department of Chemistry, Isfahan University of Technology, Isfahan 84156, Iran
}

\begin{abstract}
Um procedimento relativamente simples e sensível com detecção espectrofluorimétrica foi desenvolvido para a determinação de cistina e cisteína por sistema de injeção em fluxo com determinação seqüencial. Esse método é fundamentado na redução de Tl(III) com cisteína em meio ácido, produzindo o reagente fluorescente $\mathrm{TlCl}_{3}{ }^{2-}\left(\lambda_{\mathrm{ex}}=227 \mathrm{~nm}, \lambda_{\mathrm{em}}=419 \mathrm{~nm}\right)$. Antes da injeção, a solução da amostra foi dividida em dois fluxos. O primeiro fluxo foi tratado com coluna de redução de Cd e então refluxado com a solução do carregador para reagir em pH 5,0 com Tl(III), passado através de uma cela de reação de $100 \mathrm{~cm}$ e posteriormente para a cela fluxo do espectrofluorímetro, onde a intensidade de fluorescência foi medida $\left(\lambda_{\mathrm{ex}}=227 \mathrm{~nm}, \lambda_{\mathrm{em}}=419 \mathrm{~nm}\right)$. Esse sinal está relacionado às concentrações de cistina e cisteína. O segundo fluxo da solução de amostra foi injetado diretamente no fluxo carregador para reagir e, então, pela cela de reação e detector para medida da intensidade de fluorescência. $\mathrm{O}$ sinal nessa etapa é relacionado apenas à cisteína. Assim, o conteúdo de cistina foi determinado diretamente da diferença entre os dois sinais. Cistina e cisteína podem ser determinadas no intervalo de 0,10 a 5,50 $\mu \mathrm{mol} \mathrm{L}^{-1}$ e 0,20 a $8,0 \mu \mathrm{mol} \mathrm{L}{ }^{-1}$, respectivamente, em uma razão de 20 amostras por hora. O limite de detecção $(3 \mathrm{~s} / \mathrm{k})$ foi $0,10 \mu \mathrm{mol} \mathrm{L} \mathrm{L}^{-1}$ para os dois analitos. Os desvios padrões relativos para a determinação de dez replicatas de 4,0 e $3,5 \mu \mathrm{mol} \mathrm{L^{-1 }}$ de cistina ou cisteína foram $1,1 \%$ e $1,8 \%$, respectivamente. A influência de substâncias interferentes foi estudada. O método proposto foi aplicado com sucesso na determinação seqüencial de ambos analitos em amostras farmacêuticas.
\end{abstract}

A relatively simple and sensitive procedure with spectrofluorimetric detection was developed for the determination of cystine and cysteine by flow injection system with sequential determination. This method is based on the reduction of $\mathrm{Tl}(\mathrm{III})$ with cysteine in acidic media, producing a fluorescence reagent, $\mathrm{TlCl}_{3}^{2-}\left(\lambda_{\mathrm{ex}}=227 \mathrm{~nm}, \lambda_{\mathrm{em}}=419 \mathrm{~nm}\right)$. Before injection, the sample solution was divided into two streams. The first stream was treated with $\mathrm{Cd}$ reduction column and then joined with the carrier to react with $\mathrm{Tl}(\mathrm{III})$ at $\mathrm{pH} 5.0$ and then passed through a $100 \mathrm{~cm}$ reaction coil to the flow cell of the spectrofluorimeter, where the fluorescence intensity was measured $\left(\lambda_{\mathrm{ex}}=227 \mathrm{~nm}, \lambda_{\mathrm{em}}=419 \mathrm{~nm}\right)$. This signal is related to cystine and cysteine concentrations. The second stream of sample solution was injected directly into the carrier stream to react with the reagents and then passed through the reaction coil and detector for measuring the fluorescence intensity. The signal in this step is related only to cysteine. Thus, the cystine content was determined directly from difference of the two signals. Cystine and cysteine can be determined in the range of 0.10 to $5.50 \mu \mathrm{mol} \mathrm{L}-1$ and 0.20 to $8.0 \mu \mathrm{mol} \mathrm{L}^{-1}$, respectively, at a rate of 20 samples per hour. The limit of detection $(3 \mathrm{~s} / \mathrm{k})$ was $0.10 \mu \mathrm{mol} \mathrm{L} \mathrm{L}^{-1}$ for both analytes. The relative standard deviations for ten replicates determination of 4.0 and $3.5 \mu \mathrm{mol} \mathrm{L}^{-1}$ cystine or cysteine were $1.1 \%$ and $1.8 \%$, respectively. The influence of potential interfering substances was studied. The proposed method was successfully applied to the sequential determination of both analytes in pharmaceutical samples.

Keywords: cysteine, cystine, sequential determination, spectrofluorimetry

\section{Introduction}

L-cystine and L-cysteine are two nonessential amino acids with significant biological importance. L-cysteine participates in a variety of important cellular functions,

*e-mail: ensafi@cc.iut.ac.ir among others protein synthesis, detoxification and metabolism. Disorders of cysteine metabolism include cystinosis, an antosomal recessive disease produced by a defect in lysosomal transport and cystinuria, a common heritable disorder of amino acids transport. Altered levels of cysteine have been implicated in hyperhomocysteinemia and in a number of pathological conditions, including 
Alzheimer's and Parkinson's disease. The oxidized derivative of L-cysteine (L-cystine) has additional metabolic roles such as stabilization of the tertiary structure of proteins (via disulfide bonds). Thereby, cysteine and cystine are widely used in many pharmaceutical products and as supplement in some foods. ${ }^{1-3}$ As cysteine is readily oxidized to cystine in air, and cystine is hydrolyzed to cysteine in water, they are often presented together (in hair, liver, horn, etc.). So, the determination of cysteine and cystine in biological fluids, clinical investigations and pharmaceutical preparations are of great importance. Several different methods have been developed for the determination of cysteine and/or cystine. ${ }^{4-6}$ However, the analysis of mixtures of cysteine and cystine has rarely been performed by non-chromatographic techniques. ${ }^{1,3,7,8}$ Perez-Ruiz et al. ${ }^{1}$ introduced a flow injection chemiluminescence method for just L-cysteine based on the reaction of L-cysteine with tris(2,2'-bipyridyl) ruthenium(II) and peroxydisulphate under UV irradiation to produce chemiluminescence, with limit of determination of $0.5 \mu \mathrm{mol} \mathrm{L}{ }^{-1}$. The proposed method suffers from many amino acids interference. Pérez-Ruiz et $a l .{ }^{3}$ introduced a flow injection spectrophotometric method based on the inhibitory effect of cysteine/cystine on the oxidation of thiamine by mercury(II). The linear calibration range was $10-100 \mu \mathrm{mol} \mathrm{L} \mathrm{L}^{-1}$, and the method suffers from many interferences. Chrastil ${ }^{7}$ used a flow injection spectrophotometric method based on the formation of a colored complex with osmic acid for determination of cysteine and/or cystine with low limit of detection of $10 \mu \mathrm{mol} \mathrm{L}{ }^{-1}$. Tütem and $\mathrm{Apak}^{8}$ introduced a conventional spectrophotometric method for determination of cysteine/ cystine with copper(II)-neocuproin system. The method has low precision. The other reported papers introduced a relatively sensitive spectrofluorimetric method for determination of only L-cysteine, ${ }^{6,9}$ with limit of detection of $0.1 \mu \mathrm{mol} \mathrm{L}{ }^{-1}$, and $0.04 \mu \mathrm{mol} \mathrm{L}{ }^{-1}$, respectively. No any of the reported method is able to measure both of L-cysteine and cystine together.

A spectrophotometric enzymatic determination of L-cysteine has been described by following the decrease in the absorbance of NADH through two-enzymatic reactions; L-cysteine desulfhydrase from streptococcus anginosus bacterial cells to give pyruvate and lactate dehydogenase in the presence of NADH to convert pyruvate into lactate. ${ }^{10}$ Enzymatic colorimetric method for determining L-cysteine has been also described based on the use of recombinant enzymes methionine $\alpha, \gamma$-lyase and adenosylhomocysteine hydrolase cloned from pseudomonas putida and trichomonas vaginalis, respectively. ${ }^{11}$ However, these methods involved two enzymatic reaction steps and suffer from severe interferences from methionine and homocysteine which need prior removal. ${ }^{10,11}$ Therefore, the development of a simple and selective method without tedious separation for detecting cysteine and cystine is obviously desirable.

Thallium(I) can be determined by measuring its fluorescence as $\mathrm{TlCl}_{3}{ }^{2-}$, whereas $\mathrm{Tl}(\mathrm{III})$ does not show any fluorescent characteristics. $\mathrm{Tl}(\mathrm{III}) / \mathrm{Tl}(\mathrm{I})$ system has been used as an analytical tools with flow injection analysis (FIA) manifold for speciation of $\mathrm{Tl}(\mathrm{III})$ and $\mathrm{Tl}(\mathrm{I})^{12}$ and also for determination of ascorbic acid. ${ }^{13}$ In this paper, a new, fast and relatively simple flow injection spectrofluorimetric method is proposed for sequential determination of cysteine and cystine based on reduction of cystine to cysteine and then reaction of cysteine with $\mathrm{Tl}(\mathrm{III})$ in chloride media to produce a fluorescence agent, $\mathrm{TlCl}_{3}{ }^{2-}$, by use of a suitable manifold design.

\section{Experimental}

\section{Reagents}

All solutions were prepared using reagent grade chemicals and doubly distilled water was used throughout.

Cysteine and cystine stock solutions $\left(0.0010 \mathrm{~mol} \mathrm{~L}^{-1}\right)$ were prepared by dissolving $0.0175 \mathrm{~g}$ of L-cysteine hydrochloride (Merck) and $0.0240 \mathrm{~g}$ of L-cystine (Merck) in doubly distilled water in $100 \mathrm{~mL}$ volumetric flasks, and kept in refrigerator. Those solutions were stable up to 7 days. Working standard solutions were freshly prepared by diluting the stock solutions with water.

$\mathrm{Tl}(\mathrm{III})$ stock solution $\left(0.010 \mu \mathrm{mol} \mathrm{L}{ }^{-1}\right)$ was prepared by dissolving $0.4444 \mathrm{~g}$ of $\mathrm{Tl}\left(\mathrm{NO}_{3}\right)_{3} \cdot 3 \mathrm{H}_{2} \mathrm{O}$ (Merck) in water and diluting to $100 \mathrm{~mL}$.

Potassium chloride standard solution $\left(1.0 \mathrm{~mol} \mathrm{~L}^{-1}\right)$ was prepared by dissolving $7.456 \mathrm{~g}$ of $\mathrm{KCl}$ (Merck) in water and diluting to $100 \mathrm{~mL}$.

Buffer solutions ( $\mathrm{pH} 2$ to 10) were prepared from universal buffer systems (phosphoric, acetic and boric acid) from $0.04 \mathrm{~mol} \mathrm{~L}^{-1}$ solution of each acid and $0.20 \mathrm{~mol} \mathrm{~L}^{-1}$ $\mathrm{NaOH}$ or $0.50 \mathrm{~mol} \mathrm{~L}^{-1} \mathrm{HCl}$ solution using a $\mathrm{pH}$-meter.

\section{Apparatus}

A diagram of the flow system employed is shown in Figure 1. The fluorescence intensity was measured on a Shimadzu Model RF-535 spectrofluorimeter equipped with a flow through cell $(20 \mu \mathrm{L}$ volume and $1.0 \mathrm{~cm}$ optical path length) equipped with a Shimadzu signal processing (Model C-R4AX Chromatopac). A 12-channels peristaltic pump (Desaga, Model PLG) with silicon rubber tubes $(1.0 \mathrm{~mm}$ i.d.) was used. PTFE mixing joints and PTFE tubing $(1.0 \mathrm{~mm}$ i.d.) was used for the connections and for the reaction coil. A 
cadmium reduction column, home-made, $(1.5 \mathrm{~mm}$ i.d., $10 \mathrm{~cm}$ length, with $10 \mathrm{~g}$ of cadmium granule, about $0.2 \mathrm{~mm}$ particle size) was used for on-line reduction of cystine to cysteine. A thermostat water bath (Gallen-Kamp, BLG) was used and adjusted at temperature of $25.0 \pm 0.1^{\circ} \mathrm{C}$. Sample solutions were injected using a six port rotary Supelco valve. A Jasco spectrofluorimeter, Model FP-750, was used for recording the spectra of the reaction solution (Tl(III) plus cysteine in acidic media). A pH-meter, Corning Model 140, equipped with a combined Metrohm electrode, Model 6.0202.100, was used for $\mathrm{pH}$ determination of the buffer solutions.

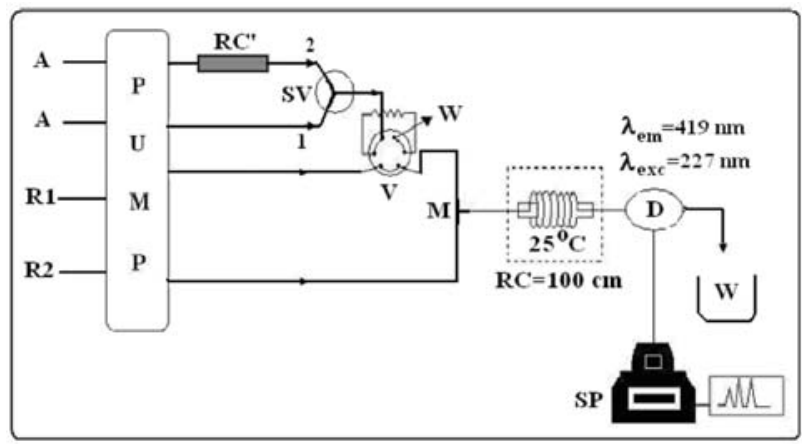

Figure 1. Schematic representation of the FIA manifold employed for the sequential determination of cysteine and cystine. R1, carrier; R2, a mixture solution of the $\mathrm{Tl}^{3+}$ and potassium chloride at $\mathrm{pH}$ 5.0; $\mathrm{RC}^{\prime}$, reduction column; $\mathrm{SV}$, selection valve; $\mathrm{V}$, injection valve; $\mathrm{M}$, mixing zone; $\mathrm{RC}$, reaction coil; $\mathrm{D}$, detector; SP, signal processor; A, sample solution, and W, waste.

\section{Recommended procedure}

As shown in Figure 1, solutions containing carrier $\left(\mathrm{H}_{2} \mathrm{O}\right.$, (R1)), Tl(III) solution at pH 5.0 (R2) and sample solution (A), are pumped at $0.48 \mathrm{~mL} \mathrm{~min}^{-1}$ (for each channel) via a peristaltic pump. The standard solution containing 0.2-8.0 $\mu \mathrm{mol} \mathrm{L} \mathrm{L}^{-1}$ cysteine and 0.1-5.5 $\mu \mathrm{mol} \mathrm{L} \mathrm{L}^{-1}$ cystine was injected into the carrier stream via sample injection valve. The sample solution was delivered to the sample injection valve using a selection valve (SV). The first stream of the sample solution was injected, and after with a reaction mixture of $\mathrm{Tl}(\mathrm{III})-\mathrm{KCl}$ solution at $\mathrm{pH} 5.0$, it was passed to the sample flow cell of the spectrofluorimeter, where the fluorescence at $419 \mathrm{~nm}$ was measured as the initial cysteine content (first peak). The second stream of the sample solution was passed through Cd-reduction column and then injected into the carrier stream and after reaction with $\mathrm{Tl}(\mathrm{III})-\mathrm{KCl}$ solution at $\mathrm{pH} 5.0$ it was passed to the sample flow cell of the spectrofluorimeter, where the fluorescence was measured at $419 \mathrm{~nm}$. This signal is related to the concentration of both cysteine and cystine (second peak). The concentration of cysteine and cystine were evaluated from the peak height measurements by using a calibration curve prepared from the results obtained after the analysis of standards.

\section{Real sample analysis}

For the NAC (N-acetyl cysteine) tablet, twenty tablets of each brand were grind and mixed well. Then $0.3550 \mathrm{~g}$ of the sample (equal to weight of one tablet) was dissolved in water in a $50 \mathrm{~mL}$ beaker. The mixture was filtered using a filter paper (Whatman No. 1). The filtrate was collected and diluted with water in a $50 \mathrm{~mL}$ volumetric flask. River water samples were passed through a filter paper (Whatman No. 1) and then used directly for analysis.

\section{Results and Discussion}

Cysteine is oxidized by $\mathrm{Tl}(\mathrm{III})$ in weak acidic media ( $\mathrm{pH} 5$ ) to produce $\mathrm{Tl}(\mathrm{I})$, which forms a stable anionic complex, $\mathrm{TlCl}_{3}{ }^{2-}$, in the presence of chloride ions. This complex has a violet fluorescence, ${ }^{14}$ whereas $\mathrm{Tl}(\mathrm{III})$ does not have any fluoresce. Figure 2 shows the fluorescence signal for cysteine recorded with time. Cystine does not have any effect on the $\mathrm{Tl}(\mathrm{III})-\mathrm{KCl}$ mixture in acidic media, indicating that cystine could not reduce $\mathrm{Tl}(\mathrm{III})$ to $\mathrm{Tl}(\mathrm{I})$. On the other hand, cysteine reduces $\mathrm{Tl}(\mathrm{III})$ to $\mathrm{Tl}(\mathrm{I})$. Therefore, by on-line reducing of cystine to cysteine and designing a suitable FIA manifold it is possible to measure both of the two compounds.

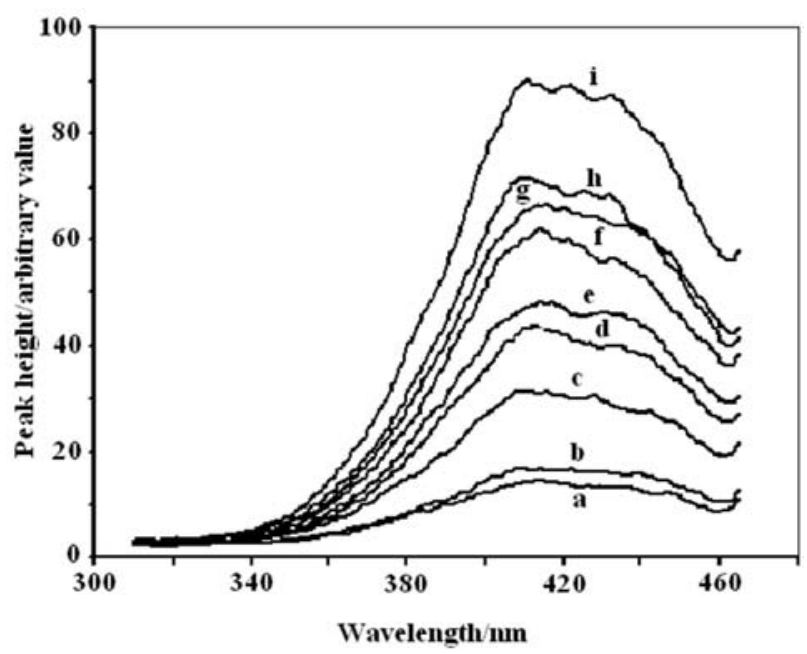

Figure 2. Fluorescence spectrum with time resulted for reaction of cysteine with $\mathrm{Tl}^{3+}$ solution at various time intervals; a) blank solution, b) after $45 \mathrm{~s}$, c) after $135 \mathrm{~s}$, d) after $225 \mathrm{~s}$, e) after $315 \mathrm{~s}, \mathrm{f}$ ) after 405, g) after $495 \mathrm{~s}$, h) after $585 \mathrm{~s}$, and i) after $675 \mathrm{~s}$ of cysteine addition. Conditions: $\mathrm{Tl}^{3+}$, $0.000030 \mathrm{~mol} \mathrm{~L}^{-1}$; KCl, $0.15 \mathrm{~mol} \mathrm{~L}^{-1}$; $\mathrm{pH}, 5.0 ; 3.0 \mu \mathrm{mol} \mathrm{L}^{-1}$ cysteine.

\section{Influence of chemical variables}

The influence of $\mathrm{pH}$ and $\mathrm{Tl}(\mathrm{III})$ and $\mathrm{KCl}$ concentrations on the peak height (sensitivity) were investigated using a $200 \mu \mathrm{L} 1.0 \times 10^{-5} \mathrm{~mol} \mathrm{~L}^{-1}$ cysteine, a reaction coil length of $170 \mathrm{~cm}$ and a pump flow rate of $0.23 \mathrm{~mL} \mathrm{~min}^{-1}$ (for each channel) at $25^{\circ} \mathrm{C}$. 
The influence of $\mathrm{pH}$ on the sensitivity was studied with $2.0 \times 10^{-5} \mathrm{~mol} \mathrm{~L}^{-1} \mathrm{Tl}(\mathrm{III})$ and $0.150 \mathrm{~mol} \mathrm{~L}^{-1} \mathrm{KCl}$ solution, in the range 2.0-10.0. The results showed that the fluorescence signal increased slowly with increasing $\mathrm{pH}$ from 2.0 to 5.0 and then decreased sharply up to 7.0 and finally reached to very low intensity at $\mathrm{pH}$ 8.0. This is due to the fact that in higher acidity condition, $\mathrm{H}^{+}$ions cause the decreasing of the cysteine oxidation rate to cystine by $\mathrm{Tl}(\mathrm{III})$, because $\mathrm{H}^{+}$ion is one of the products of the oxidation reaction of cysteine to cystine. Further, the oxidation ability of Tl(III) decreases in alkaline solution. Therefore, a pH of 5.0 was selected as the optimum $\mathrm{pH}$.

The influence of $\mathrm{Tl}$ (III) concentration on the fluorescence signal was studied in the range of $5.0 \times 10^{-6}$ to $1.0 \times 10^{-3} \mathrm{~mol} \mathrm{~L}^{-1}$ at $\mathrm{pH} 5.0$ and $25^{\circ} \mathrm{C}$. The results showed that the sensitivity is increased with increasing $\mathrm{Tl}(\mathrm{III})$ concentration up to $1.0 \times 10^{-5} \mathrm{~mol} \mathrm{~L}^{-1}$, because increasing the amount of reagents results in increasing formation of the fluorescence product, $\mathrm{TlCl}_{3}{ }^{2-}$. However, the sensitivity decreases for Tl(III) concentrations over $1.0 \times 10^{-5} \mathrm{~mol} \mathrm{~L}^{-1}$, which can be due to self quenching. Thus, $1.0 \times 10^{-5} \mathrm{~mol} \mathrm{~L}^{-1}$ $\mathrm{Tl}(\mathrm{III})$ was selected as optimum.

A chloride ion has an important role in the fluorescence signal of $\mathrm{Tl}(\mathrm{I})$, due to formation of $\mathrm{TlCl}_{3}{ }^{2-}$. The influence of chloride ion concentration on the sensitivity ( $\mathrm{pH}$ 5.0) was studied in the range $0.05-0.35 \mathrm{~mol} \mathrm{~L}^{-1}$, using $\mathrm{KCl}$ solution. The results showed that addition of $\mathrm{KCl}$ up to $0.30 \mathrm{~mol} \mathrm{~L}^{-1}$ had a considerable effect on increasing the sensitivity and, beyond that, the signal leveled off. Therefore, $0.30 \mathrm{~mol} \mathrm{~L}^{-1}$ $\mathrm{KCl}$ was selected for the study.

\section{Influence of manifold variables and reduction column}

The effects of reaction coil length, pump flow rate and sample volume on the sensitivity were studied with the optimum reagents concentration at $25{ }^{\circ} \mathrm{C}$ and with $1.0 \times 10^{-5} \mathrm{~mol} \mathrm{~L}^{-1}$ cysteine. The peak height depends on the residence time of the sample zone in the system (tube length and flow rate). Reaction coils of 50 to $250 \mathrm{~cm}$ were tested. A little increasing in sensitivity was observed when the length of the reaction coil was increased from 50 to $100 \mathrm{~cm}$, above which the signal decreased slightly due to increasing the dispersion. Therefore, a $100 \mathrm{~cm}$ coil length was selected for the study.

The influence of flow rate on the sensitivity was studied in the range $0.17-0.58 \mathrm{~mL} \mathrm{~min}^{-1}$ for each channel. At low flow rates the fluorescence signal is higher, but the peaks are broadened and the analysis time is longer. Therefore, for a compromise between reaction time and sensitivity, a flow rate of $0.48 \mathrm{~mL} \mathrm{~min}{ }^{-1}$ was selected for each channel.
The influence of sample loop volume on the sensitivity was studied under the optimum reagents and manifold conditions at $25^{\circ} \mathrm{C}$. The sample volume was varied between 145 to $300 \mu \mathrm{L}$. The results showed that the peak height increased with increasing injected volume up to $200 \mu \mathrm{L}$, above which they remained almost constant. Thus, a sample volume of $200 \mu \mathrm{L}$ was chosen for further experiments.

The influence of temperature on the sensitivity was studied in the range of $5-50{ }^{\circ} \mathrm{C} .25^{\circ} \mathrm{C}$ was selected because it is more comfort.

The influence of Cd reduction column length on the measurement sensitivity of cystine was studied in the range $2.5-12.5 \mathrm{~cm}$. The results showed that the sensitivity was increased by increasing the column length up to $10 \mathrm{~cm}$ and after that the signal leveled off. Thus, column length of $10 \mathrm{~cm}$ was selected for the reduction.

The reduction of cystine takes place in acidic media. So, the influence of $\mathrm{HCl}$ concentration on the efficiency of the reduction column was studied in the range $1.0 \times 10^{-4}-0.03 \mathrm{~mol} \mathrm{~L}^{-1}$ (Figure 3). The results showed that by increasing $\mathrm{HCl}$ concentration up to $0.02 \mathrm{~mol} \mathrm{~L}^{-1}$, the efficiency of the reduction was increased, whereas at higher concentration it remains almost constant. This is due to the fact that, the reduction of cystine takes place in acidic media. On the other hand, regeneration of column can be done in acidic solution successfully. For these reasons, $0.02 \mathrm{~mol} \mathrm{~L}^{-1}$ $\mathrm{HCl}$ was selected sample solution in this study.

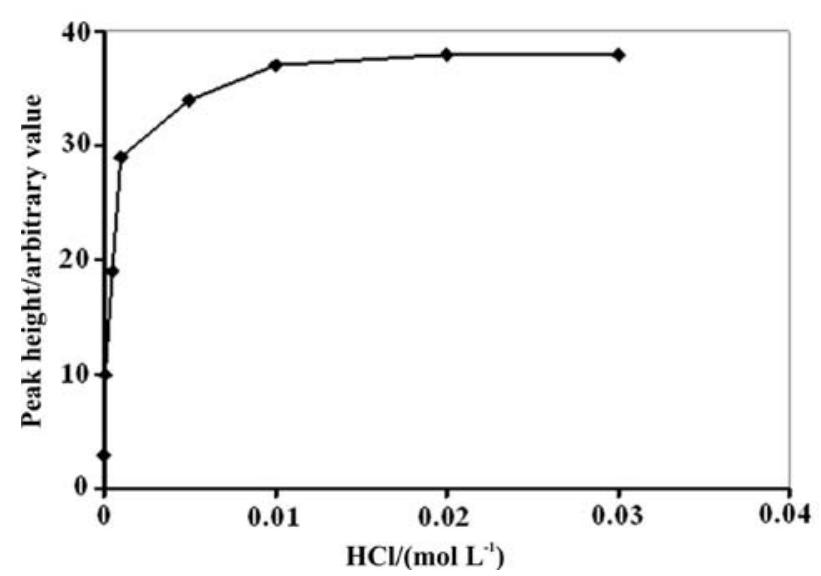

Figure 3. Effect of $\mathrm{HCl}$ concentration on the reduction column efficiency. Conditions: $\mathrm{Tl}^{3+}, 0.000010 \mathrm{~mol} \mathrm{~L}^{-1}$; $\mathrm{KCl}, 0.3 \mathrm{~mol} \mathrm{~L}^{-1}$; pH, 5.0; cystine, $0.000010 \mathrm{~mol} \mathrm{~L}^{-1}$; Reaction coil length, $100 \mathrm{~cm}$; Injection volume, $200 \mu \mathrm{L}$; Flow rate, $0.48 \mathrm{~mL} \mathrm{~min}^{-1}$ for each channel and temperature of $25^{\circ} \mathrm{C}$.

\section{Calibration graph and analysis of mixtures}

Under the optimum reagents concentration and manifold variables, the calibration equation for the dependence of fluorescence signal on cysteine concentration in the range $0.2-8.0 \mu \mathrm{mol} \mathrm{L}^{-1}$ was: 
$\mathrm{I}_{\mathrm{Fl}}=5.9313+17.449 \mathrm{C}_{\text {cysteine }}\left(\mathrm{r}^{2}=0.9992\right)$, and for cystine in the range 0.1 to $5.5 \mu \mathrm{mol} \mathrm{L}-1$ with calibration equation of $\mathrm{I}_{\mathrm{Fl}}=6.3312+28.019 \mathrm{C}_{\text {cystine }}\left(\mathrm{r}^{2}=0.9986\right)$, where $\mathrm{C}$ is concentration of cysteine or cystine in $\mu \mathrm{mol} \mathrm{L} \mathrm{L}^{-1}$. A typical FI signals is shown in Figure 4.

The limit of detection, $3 \mathrm{~s} / \mathrm{k}$ (three times blank standard deviation/slope of analytical curve) was $0.1 \mu \mathrm{mol} \mathrm{\textrm {L } ^ { - 1 }}$ for both species. The limit of quantification was $0.12 \mu \mathrm{mol} \mathrm{L} \mathrm{L}^{-1}$ for the both species.

The relative standard deviations for ten replicates determination of 4.0 and $3.5 \mu \mathrm{mol} \mathrm{\textrm {L } ^ { - 1 }}$ cystine or cysteine were $1.1 \%$ and $1.8 \%$, respectively. The sampling rate was about 20 samples per hour.

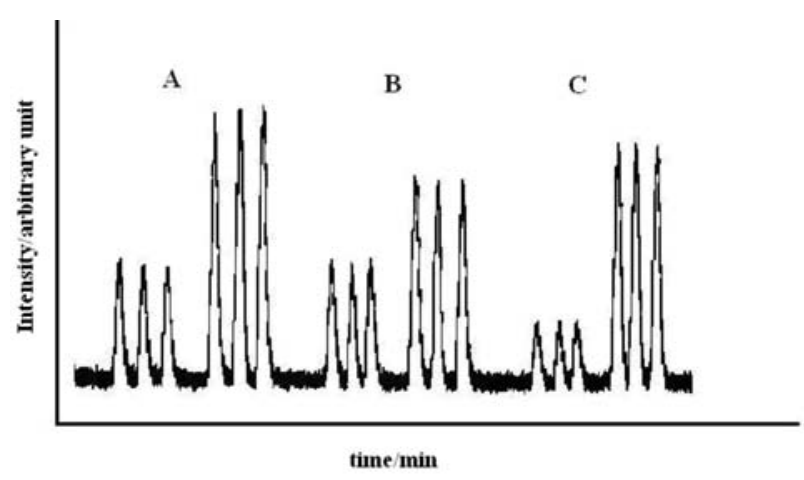

Figure 4. Typical FIA signals for cysteine and cystine mixture determination under the optimum conditions; A) $1.60 \mu \mathrm{mol} \mathrm{L} \mathrm{L}^{-1}$ of cysteine plus $1.60 \mu \mathrm{mol} \mathrm{L}-1$ cystine; B) $0.80 \mu \mathrm{mol} \mathrm{L}{ }^{-1}$ cystine plus $1.60 \mu \mathrm{mol} \mathrm{L}^{-1}$ cysteine; C) $1.60 \mu \mathrm{mol} \mathrm{L}-1$ cystine plus $0.80 \mu \mathrm{mol} \mathrm{L}^{-1}$ cysteine.

\section{Influence of foreign substances}

In order to validate of the possible analytical applications of the method, the effect of various compounds on the determination of $5.0 \mu \mathrm{mol} \mathrm{\textrm {L } ^ { - 1 }}$ cysteine were investigated. (Table 1). The potential interfering substances are added to the sample solution and the cysteine was determined as the proposed method. The tolerance limit was defined as the concentration of added species causing less than $3 \%$ relative error. The results showed that many substances especially amino acids did not interfere in the determination of cysteine and cystine.
Table 1. Effect of foreign substances in cysteine determination

\begin{tabular}{|c|c|c|}
\hline Species & $\begin{array}{l}\text { Tolerance Limit } \\
\left(\mathrm{m}_{\text {Species }} / \mathrm{m}_{\text {Cysteine }}\right)\end{array}$ & $\begin{array}{l}\text { Signal } \\
\text { Change }\end{array}$ \\
\hline $\begin{array}{l}\text { Glycine, Alanine, L- Lysine, L-Leucine, } \\
\text { L-Proline, L-Threonine, L-Valine, Cystine, } \\
\mathrm{L}-\text { Asparagine, L-Serine, Tartaric acid, } \\
\text { Citric acid, } \mathrm{NaCl} \text {, EDTA, Sacarose, } \\
\text { Glucose, Fructose, Lactose, } \mathrm{Zn}^{2+}, \mathrm{Mg}^{2+} \text {, } \\
\mathrm{Ca}^{2+}, \mathrm{SO}_{3}^{2-}, \mathrm{F}^{-}, \mathrm{Cr}_{2} \mathrm{O}_{7}^{2-}, \mathrm{NH}_{4}^{+}, \mathrm{SCN}^{-}, \mathrm{IO}_{4}^{-} \text {, } \\
\mathrm{ClO}_{3}^{-}, \mathrm{S}_{2} \mathrm{O}_{5}^{-}, \mathrm{BrO}_{3}^{-}, \mathrm{Ce}^{3+}, \mathrm{CO}_{3}^{2-}\end{array}$ & $1000^{*}$ & $<3 \%$ \\
\hline L-Asparatic acid, Urea & $1000^{*}$ & $+23 \%$ \\
\hline $\mathrm{Cd}^{2+}$ & $1000^{*}$ & $-17 \%$ \\
\hline L-Asparatic acid, Urea, $\mathrm{Cd}^{2+}$ & 200 & $<3 \%$ \\
\hline $\mathrm{Sn}^{2+}$ & $1000^{*}$ & $-58 \%$ \\
\hline $\mathrm{Sn}^{2+}$ & 30 & $<3 \%$ \\
\hline L-Hystidine & $1000^{*}$ & $+37 \%$ \\
\hline Methionine & $1000^{*}$ & $39 \%$ \\
\hline L-Hystidine, Methionine & 10 & $3 \%$ \\
\hline
\end{tabular}

*Maximum concentration of the reagent tested.

\section{Applications}

To evaluate the applicability of the proposed method for real samples analysis, water and pharmaceutical samples were selected for determination of cysteine and/or cystine. The sample solutions were prepared as described before. The standard addition method was used by spiking of the samples with cysteine and/or cystine. Then the cysteine and/or cystine were determined using the recommended procedure. Tables 2 and 3 summarize the analytical results for the determination of cysteine and cystine in pharmaceutical formulations and river water by the proposed method. The good recoveries of the spiked samples confirm the ability of the proposed method to measure cysteine and/or cystine. The results show that the flow injection allows us to determine rapidly the same and different concentration levels of cysteine and cystine with good recoveries.

Table 2. Determination of cysteine and cystine in pharmaceutical (NAC tablet)

\begin{tabular}{|c|c|c|c|c|c|c|}
\hline Sample & $\begin{array}{l}\text { Cysteine Added / } \\
\left.(\mu \mathrm{mol} \mathrm{L})^{-1}\right)\end{array}$ & $\begin{array}{l}\text { Cystine Added / } \\
\left.(\mu \mathrm{mol} \mathrm{L})^{-1}\right)\end{array}$ & $\begin{array}{l}\text { Cysteine Found / } \\
\qquad(\mu \mathrm{mol} \mathrm{L}-1)\end{array}$ & Recovery / (\%) & $\begin{array}{l}\text { Cystine Found / } \\
\left.(\mu \mathrm{mol} \mathrm{L})^{-1}\right)\end{array}$ & Recovery / (\%) \\
\hline 1 & ---- & ---- & $2.80( \pm 0.05) \times 10^{-6}$ & --- & $5.12( \pm 0.07) \times 10^{-7}$ & ---- \\
\hline 2 & $8.00 \times 10^{-7}$ & $8.00 \times 10^{-7}$ & $8.20( \pm 0.07) \times 10^{-7}$ & 102.5 & $8.21( \pm 0.07) \times 10^{-7}$ & 102.5 \\
\hline 3 & $1.20 \times 10^{-6}$ & $1.20 \times 10^{-6}$ & $1.22( \pm 0.08) \times 10^{-6}$ & 102.0 & $1.15( \pm 0.08) \times 10^{-6}$ & 96.0 \\
\hline 4 & $1.60 \times 10^{-6}$ & $1.60 \times 10^{-6}$ & $1.72( \pm 0.09) \times 10^{-6}$ & 107.0 & $1.57( \pm 0.09) \times 10^{-6}$ & 98.0 \\
\hline
\end{tabular}


Table 3. Determination of cysteine and cystine in river water (Zayande-Rood)

\begin{tabular}{|c|c|c|c|c|c|c|}
\hline Sample & $\begin{array}{c}\text { Cysteine Added / } \\
\left(\mu \mathrm{mol} \mathrm{L} \mathrm{L}^{-1}\right)\end{array}$ & $\begin{array}{l}\text { Cystine Added / } \\
\left.(\mu \mathrm{mol} \mathrm{L})^{-1}\right)\end{array}$ & $\begin{array}{l}\text { Cysteine Found / } \\
\left.(\mu \mathrm{mol} \mathrm{L})^{-1}\right)\end{array}$ & Recovery / (\%) & $\begin{array}{l}\text { Cystine Found / } \\
\left.(\mu \mathrm{mol} \mathrm{L})^{-1}\right)\end{array}$ & Recovery / (\%) \\
\hline 1 & --- & --- & --- & ---- & ---- & ---- \\
\hline 2 & $8.00 \times 10^{-7}$ & $8.00 \times 10^{-7}$ & $8.15( \pm 0.05) \times 10^{-7}$ & 102.0 & $8.5( \pm 0.08) \times 10^{-7}$ & 107.0 \\
\hline 3 & $1.20 \times 10^{-6}$ & $1.20 \times 10^{-6}$ & $1.16( \pm 0.07) \times 10^{-6}$ & 99.0 & $1.28( \pm 0.08) \times 10^{-6}$ & 107.0 \\
\hline 4 & $1.60 \times 10^{-6}$ & $1.60 \times 10^{-6}$ & $1.56( \pm 0.08) \times 10^{-6}$ & 97.5 & $1.66( \pm 0.10) \times 10^{-6}$ & 104.0 \\
\hline
\end{tabular}

\section{Conclusions}

The new method developed for flow injection determination of cysteine and cystine is relatively simple, sensitive and rapid in real sample analyses. The sensitivity and reproducibility are coupled with a high speed and safety analysis with the proposed FIA technique. The resulting time analysis from the chosen conditions was equal to 3 min per analysis.

\section{Acknowledgments}

The authors acknowledge the University of Arkansas in Fayetteville (Foundation, CHE-0719097) and Isfahan University of Technology Research Council, and Center of Excellence in Sensors (IUT) for support of this work.

\section{References}

1. Pérez-Ruiz, T.; Martínez-Lozano, C.; Tomás, V.; Martín, J.; Talanta 2002, 58, 987.

2. Zhu, X.; Li, Y.; Zhu, G.; Anal. Sci. 2003, 19, 575.
3. Pérez-Ruiz, T.; Martínez-Lozano, C.; Tomás, V.; Lambertos, G.; Talanta 1991, 38, 1235,

4. Robinson, E. A.; Anal. Chim. Acta 1995, 21, 190.

5. Vinas, P.; Lopez Garcia, I.; Martinez Gil, J. A.; J. Pharm. Biomed. Anal. 1993, 11, 15.

6. Yahong, C.; Ruxiu, C.; Spectrochim. Acta, Part A 2003, 59, 3357.

7. Chrastil, J.; Analyst 1989, 114, 1133.

8. Tütem, E.; Apak, R.; Anal. Chim. Acta 1991, 255, 121.

9. Wang, H.; Wang, W. S.; Zhang, H. S.; Spectrochimica Acta, Part A 2001, 57, 2403.

10. Nishiya, Y.; Yoshida, Y.; Yoshimura, M.; Fukamachi, H.; Nakano, Y.; Biosci. Biotechnol. Biochem. 2005, 69, 2244.

11. Han, Q.; Xu, M.; Tang, L.; Sun, X.; Zhang, N.; Tan, X.; Tan, X.; Tan, Y.; Hoffman, R. M.; Clin. Chem. 2004, 50, 290.

12. Ensafi, A. A.; Rezaei, B.; Microchemical J. 1998, 60, 75.

13. Ensafi, A. A.; Rezaei, B.; Anal. Lett. 1998, 31, 333.

14. Kirkbright, G. F.; West, T. S.; Woodward, C.; Talanta 1965, 12, 517.

Received: February 21, 2008 Web Release Date: December 18, 2008 